\title{
Total and high density lipoprotein cholesterol in the serum and risk of mortality: evidence of a threshold effect
}

\author{
U GOLDBOURT E HOLTZMAN, H N NEUFELD
}

\begin{abstract}
The association of serum total and high density lipoprotein cholesterol values with 15 year mortality was examined in a cohort of 10059 Israeli male civil servants and municipal employees aged 40 and above. In 618 of 1664 deaths in the cohort $(37 \%)$ coronary heart disease was documented as the cause of death. Risk of mortality was analysed by quintiles. Neither total mortality nor coronary heart disease mortality rose with serum cholesterol concentrations up to $5.6 \mathrm{mmol} / 1(216 \mathrm{mg} /$ $100 \mathrm{ml}$ ), representing $60 \%$ of the sample. Rates rose appreciably only in the highest quintile (cholesterol concentration $>6.2 \mathrm{mmol} / 1 ;>241 \mathrm{mg} / 100 \mathrm{ml}$ ). High density lipoprotein cholesterol was similarly, although inversely, associated with total mortality when expressed as a percentage of total cholesterol. The inverse association of high density lipoprotein cholesterol with coronary heart disease mortality was, in contrast, continuous. These data support the hypothesis that over most of the range of cholesterol values coronary mortality risk and total mortality risk are nearly independent of total cholesterol and most probably independent of low density lipoprotein cholesterol values.

In multivariate analysis a low concentration of high density lipoprotein cholesterol appeared to be more predictive of mortality than a high concentration of total cholesterol. The latter was very weakly related to mortality from all causes after multivariate adjustment.

It is concluded that the findings of this and other major epidemiological studies support the notion of a
\end{abstract}

\footnotetext{
Heart Institute, Chaim Sheba Medical Center, Tel-Hashomer, and Sackler School of Medicine, Tel-Aviv, Israel

U GOLDBOURT, PHD, head, section of epidemiology and biostatistics E HOLTZMAN, MD, internal medicine senior

$\mathrm{H} N$ NEUFELD, $M D$, director and professor of medicine

Correspondence to: Dr Uri Goldbourt, Heart Institute, Sheba Medical Center, Tel-Hashomer 52621, Israel.
}

"threshold effect." Success in reducing mortality through the pharmacological reduction of serum cholesterol in hypercholesterolaemic patients does not warrant a similar approach in people with average or slightly above average values. These findings appear to provide support for a "high risk strategy" in reducing the risk of coronary heart disease.

\section{Introduction}

The Lipid Research Clinics Program of the National Heart, Lung, and Blood Institute has recently achieved success in reducing cardiac mortality and the incidence of non-fatal myocardial infarction in hypercholesterolaemic men with the use of cholestyramine resin. ${ }^{1}$ This result is certain to increase both the fervour of supporters of the "cholesterol connection" and the controversy" associated with advocating large scale dietary reforms in populations.

One of the numerous aspects of the controversy concerns the nature of the association between cholesterol and coronary heart disease. Those citing mainly "ecological correlations" have pointed out that mean concentrations of cholesterol were low in countries with a low incidence of coronary heart disease and that this proves the wisdom of reducing cholesterol concentrations across the board. ${ }^{3}{ }^{4}$ Such cross cultural correlations are, however, compatible with two settings-namely, that in which individual values within a society are correlated with risk of coronary heart disease along the whole range of cholesterol concentrations and that in which the risk of coronary heart disease is raised only in subjects with exceptionally high cholesterol concentrations.

A major controversy appears to surround this question ${ }^{5-9}$ and has profound ramifications for public health; for if a threshold exists below which it is not beneficial (in terms of risk of coronary heart disease) to reduce concentrations of cholesterol in the blood, ${ }^{9}$ the case for the population strategy ${ }^{10}$ is considerably weakened. A clear cut reduction in the incidence of coronary heart disease by dietary measures has been achieved only by the Oslo study group, ${ }^{11}$ with a mean cholesterol concentration above $7.8 \mathrm{mmol} / \mathrm{l}(300 \mathrm{mg} / 100 \mathrm{ml})$. The reduction 
associated with the use of cholestyramine resin was achieved in a sample of men with concentrations above $6.9 \mathrm{mmol} / \mathrm{l}(265 \mathrm{mg} /$ $100 \mathrm{ml}$ ) and cannot be automatically extrapolated to another form of intervention, limited to dietary measures, applied over the whole cholesterol range and for both men and women.

We have used data collected in the Israeli Ischaemic Heart Disease Study to analyse results pertaining to the controversy and examine their relevance.

\section{Methods}

In 1963 we measured the concentrations of cholesterol in the serum of 9902 male civil servants and municipal employees aged 40 and over. ${ }^{12}$ In 6547 of these the concentrations of both total cholesterol and high density lipoprotein cholesterol were assessed.

The distribution of total serum cholesterol and its association with other variables have been reported. ${ }^{13}$ Venous blood was drawn from non-fasting men after electrocardiography and physical examination but before a psychosocial and dietary survey; this was to avoid any possible stressful effect of questioning on cholesterol and blood glucose concentrations or blood pressure. Blood was collected in three vacutainer tubes, one of which was a $20 \mathrm{ml}$ tube, to which anticoagulant was not added, for collection of serum. Blood samples were kept refrigerated and taken daily in ice cooled containers to a central laboratory, where the tubes were centrifuged, the serum separated, and cells discarded. Cholesterol was determined by the Anderson and Keys ${ }^{14}$ modification of the Abell method. Control procedures for cholesterol determination have been reported. ${ }^{13}$

After precipitation of low and very low density lipoprotein cholesterol by the method of Burstein and Samaille ${ }^{15}$ cholesterol in the high density lipoprotein fraction was measured direct.

The smaller number of readings of the lipoprotein fraction (only 6547 with both total and high density lipoprotein cholesterol known) was the result of the late introduction of this test into the study protocol. The entry of examinees into the study was not correlated with any health criteria and was dictated merely by administrative convenience. The age specific mean values for cholesterol in the subjects in whom the high density lipoprotein fraction was measured were almost identical with those of the 9902 in whom total cholesterol was measured, and the association between cholesterol values at

TABLE I-Distribution of causes of mortality (1963-78)

\begin{tabular}{lccccc}
\hline & $\begin{array}{c}\text { Coronary } \\
\text { heart } \\
\text { disease }\end{array}$ & $\begin{array}{c}\text { All } \\
\text { cancers }\end{array}$ & $\begin{array}{c}\text { Cerebrovascular } \\
\text { accident }\end{array}$ & $\begin{array}{c}\text { All others } \\
\text { and } \\
\text { unknown }\end{array}$ & Total \\
\hline No $(\%)$ of deaths & $618(37 \cdot 1)$ & $366(22 \cdot 0)$ & $189(11 \cdot 4)$ & $491(29 \cdot 5)$ & $1664(100 \cdot 0)$ \\
\hline
\end{tabular}

TABLE II-Fifteen year mortality (1963-78) by quintiles of total serum cholesterol concentration in 1963

\begin{tabular}{|c|c|c|c|c|c|}
\hline \multirow{2}{*}{ Quintile } & \multicolumn{2}{|c|}{ Total serum cholesterol } & \multirow{2}{*}{$\begin{array}{c}\text { No } \\
\text { of } \\
\text { subjects }\end{array}$} & \multicolumn{2}{|c|}{$\begin{array}{l}\text { Age adjusted percentage } \\
\text { mortality }\end{array}$} \\
\hline & $\mathrm{mmol} / 1$ & $\mathrm{mg} / 100 \mathrm{ml}$ & & $\begin{array}{c}\text { All } \\
\text { causes }\end{array}$ & $\begin{array}{c}\text { Coronary } \\
\text { heart disease }\end{array}$ \\
\hline $\begin{array}{l}\text { I } \\
\text { II } \\
\text { III } \\
\text { IV } \\
\text { V }\end{array}$ & $\begin{array}{r}<4 \cdot 6 \\
4 \cdot 6 \cdot 5 \cdot 1 \\
5 \cdot 2-5 \cdot 6 \\
5 \cdot 7-6 \cdot 2 \\
>6 \cdot 2\end{array}$ & $\begin{array}{r}<176 \\
176-197 \\
198-216 \\
217-241 \\
>241\end{array}$ & $\begin{array}{l}1962 \\
1974 \\
1969 \\
2040 \\
1957\end{array}$ & $\begin{array}{l}14.8 \\
14.8 \\
14.1 \\
17.0 \\
21.7\end{array}$ & $\begin{array}{r}4.5 \\
4.9 \\
4 \cdot 4 \\
6.7 \\
10 \cdot 2\end{array}$ \\
\hline Total & & & 9902 & 16.5 & $6 \cdot 2$ \\
\hline
\end{tabular}

entry and subsequent myocardial infarction was also similar in both study groups, as we have shown previously (Goldbourt et al, paper presented at 21st annual conference on cardiovascular disease epidemiology, American Heart Association, Washington, DC, March 1981).

The division of concentrations in quintiles was as follows: for total cholesterol, $<4 \cdot 6,4 \cdot 6-5 \cdot 1,5 \cdot 2-5 \cdot 6,5 \cdot 7-6 \cdot 2$, and $>6 \cdot 2 \mathrm{mmol} / 1(<176$, 176-197, 198-216, 217-241, and $>241 \mathrm{mg} / 100 \mathrm{ml}$ ); for high density lipoprotein cholesterol, $<0.75,0.75-0.85,0.86-0.96,0.97-1.11$, and $>1.11 \mathrm{mmol} / 1(<29,29-33,34-37,38-43$, and $>43 \mathrm{mg} / 100 \mathrm{ml})$; and for high density lipoprotein cholesterol calculated as a percentage of total cholesterol, $<14,14-15,16-18,19-23$, and $>23 \%$.

Over 15 years (1963-78) the deaths of 1664 men were recorded. Of these, 1637 had had their total cholesterol concentration measured at entry and 1053 had also had their high density lipoprotein cholesterol assessed. Information on the fact of death was derived from matching with the Israeli Mortality Registry by identity card number. There were two minor sources of omission. (a) Deaths occurring in men who have emigrated and are living abroad permanently are not recorded in the registry. The number of these deaths in tenured civil servants and municipal employees whose ages ranged from 40 to around 65 at intake, rising to 55 to 80 at the end of the follow up period, was probably negligible. (b) During the last three months of 1973, after the Yom Kippur war, some deaths were recorded by name only, the identity card number being missing. This resulted in only 114 deaths being identified in our cohort in 1973, as compared with 130 in 1972,132 in 1974, and 138 in 1975. We estimate that between 10 and 20 deaths were missed. These numbers may be assumed to have had a very small effect on the rates and functional associations estimated from 1664 deaths in 10059 entrants to the study. The cause of death was documented as coronary heart disease on the basis of individual determination during 1970 and the ICD thereafter, for which a verification of a $25 \%$ sample of hospital deaths by a nosologist substantiated an $89 \%$ agreement with the diagnosis on the death certificate.

Testing the association between cholesterol concentrations and rates of mortality was carried out by a test for a linear trend in proportions, ${ }^{16}$ by fitting an exponential growth curve, ${ }^{16} \mathrm{y}=\mathrm{ae} \mathrm{e}^{\mathrm{bx}}$, assuming a normal approximation for the mortality rates, and by fitting a quadratic response curve: $y=a+b x+c^{2}$. Procedure NLIN of the statistical analysis system was utilised at the Bar-Ilan University Computer Center.

Given the large numbers, tests often produced $t$ (approximate $z$ ) statistics of size 4.5 or greater, which are associated with a virtually nil probability of a type I error. These are denoted as $p \approx 0$. Multivariate analysis of coronary heart disease mortality was carried out using the proportional hazards model. ${ }^{17}$

\section{Results}

Table I shows the distribution of the main causes of death over the 15 years, and table II gives the 15 year rates of mortality in quintiles of total cholesterol concentrations. Neither mortality from all causes nor that from coronary heart disease showed any association with cholesterol concentrations at entry in the lowest three quintiles $(5.6 \mathrm{mmol} / \mathrm{l}(216 \mathrm{mg} / 100 \mathrm{ml})$ and below), although tests for a linear trend in proportion, an exponential growth curve, and a quadratic response curve all yielded statistically significant results $(p \approx 0)$. The failure of mortality to increase linearly with cholesterol concentration did not obscure varying trends by age. Table III shows that the findings held true in all age groups $(40-49,50-59, \geqslant 60)$.

The findings in table II were strongly suggestive of a $J$ type response of mortality to increasing concentrations (percentiles) of cholesterol, and we therefore sought the nature of the curvilinearity. Table IV presents the age adjusted rates of total and coronary heart disease mortality in deciles of serum cholesterol concentrations. A

TABLE III-Serum cholesterol and subsequent mortality (1963-78) by age groups

\begin{tabular}{|c|c|c|c|c|c|c|c|c|c|c|}
\hline \multirow{2}{*}{ Age (years) } & \multirow{2}{*}{ No of subjects } & \multicolumn{2}{|c|}{ Mean cholesterol in 1963} & \multirow{2}{*}{ No $(\%)$ of deaths $1963-78$} & \multicolumn{5}{|c|}{ Deaths/1000 in cholesterol quintiles } & \multirow{2}{*}{ Mean age at death (years) } \\
\hline & & $\mathrm{mmol} / 1$ & $\mathrm{mg} / 100 \mathrm{ml}$ & & I & II & III & IV & $\mathrm{V}$ & \\
\hline $\begin{array}{l}40-49 \\
50-59 \\
\geqslant 60\end{array}$ & $\begin{array}{r}5343 \\
3619 \\
940\end{array}$ & $\begin{array}{l}5 \cdot 3 \\
5.5 \\
5 \cdot 6\end{array}$ & $\begin{array}{l}205 \\
214 \\
215\end{array}$ & $\begin{array}{l}459(8 \cdot 6) \\
793(21 \cdot 9) \\
385(41 \cdot 0)\end{array}$ & $\begin{array}{r}77 \\
192 \\
383\end{array}$ & $\begin{array}{r}69 \\
210 \\
360\end{array}$ & $\begin{array}{r}77 \\
179 \\
354\end{array}$ & $\begin{array}{r}87 \\
224 \\
427\end{array}$ & $\begin{array}{l}127 \\
227 \\
491\end{array}$ & $\begin{array}{l}54 \cdot 4 \\
63.9 \\
71 \cdot 4\end{array}$ \\
\hline Total & 9902 & $5 \cdot 4$ & 209 & $1637(16.5)$ & 148 & 148 & 141 & 170 & 217 & $63 \cdot 0$ \\
\hline
\end{tabular}


trend of rising total and coronary heart disease mortality was evident only at the seventh or eighth decile. The figure shows the best fitting curves based on cholesterol deciles and the actually observed mortality rates. For expected (on the basis of an exponential curve) mortality rates the function obtained was $y=6.202 \mathrm{e}^{4 \cdot 42} \times 10^{-3}$. The $95 \%$ confidence interval for the coefficient $\mathrm{b}$ was between $2.45 \times 10^{-3}$ and $6.40 \times 10^{-3}$. The best fitting quadratic response curve was $y=$ $36 \cdot 35-0 \cdot 264 x+7 \cdot 7 x^{2} \times 10^{-4}$, where $x^{2}$ represents the squared cholesterol value. Both the linear $\left(95^{\circ}\right.$, confidence interval between -0.499 and -0.030 ) and quadratic $\left(95^{\circ}{ }_{0}\right.$ confidence interval between $2.3 \times 10^{-4}$ and $13.1 \times 10^{-4}$ ) terms were significantly different from zero $(p<0.01)$. The significance of the latter implies that the association between cholesterol and mortality departs significantly from linearity. The figure shows that the quadratic model fits the data somewhat better than the exponential one, although both fail to account fully for the total lack of rising mortality trend in the lowest deciles.

\section{HIGH DENSITY LIPOPROTEIN CHOLESTEROL}

Table $\mathrm{V}$ gives the age adjusted mortality rates for each quintile of high density lipoprotein cholesterol expressed both in absolute concentration and as a percentage of the total serum cholesterol concentration. The rates declined noticeably. As a rule, associations of mortality (total or due to coronary heart disease) with high density lipoprotein cholesterol are reinforced when the latter is expressed as a percentage of total cholesterol. The lowest quintile/highest quintile age adjusted relative risk was $3 \cdot 70$.

Table VI shows the age specific association of high density lipoprotein cholesterol as a percentage of total cholesterol with mortality. The largest decrement of total mortality appeared to be associated with avoidance of quintile I (high density lipoprotein cholesterol $<14 \%$ ).

Table VII gives the estimated relative risk of mortality from

TABLE IV-Fifteen year mortality (1963-78) by deciles of total serum cholesterol

\begin{tabular}{|c|c|c|c|c|c|}
\hline \multirow{2}{*}{ Decile } & \multicolumn{2}{|c|}{ Total serum cholesterol } & \multirow{2}{*}{$\begin{array}{c}\text { No } \\
\text { of } \\
\text { subjects }\end{array}$} & \multicolumn{2}{|c|}{$\begin{array}{l}\text { Age adjusted percentage } \\
\text { mortality }\end{array}$} \\
\hline & $\mathrm{mmol} / 1$ & $\mathrm{mg} / 100 \mathrm{ml}$ & & $\begin{array}{l}\text { All } \\
\text { causes }\end{array}$ & $\begin{array}{c}\text { Coronary } \\
\text { heart disease }\end{array}$ \\
\hline $\begin{array}{l}\text { I } \\
\text { II } \\
\text { III } \\
\text { IV } \\
\text { V } \\
\text { VI } \\
\text { VII } \\
\text { VIII } \\
\text { IX } \\
\text { X }\end{array}$ & $\begin{array}{r}<4 \cdot 2 \\
4 \cdot 2-4 \cdot 6 \\
4 \cdot 7-4 \cdot 8 \\
4 \cdot 9-5 \cdot 1 \\
5 \cdot 2-5 \cdot 3 \\
5 \cdot 4-5 \cdot 6 \\
5 \cdot 7-5 \cdot 9 \\
6 \cdot 0-6 \cdot 2 \\
6 \cdot 3-6 \cdot 7 \\
>6 \cdot 7\end{array}$ & $\begin{array}{r}<161 \\
161-176 \\
177-187 \\
188-197 \\
198-206 \\
207-216 \\
217-227 \\
228-241 \\
242-260 \\
260\end{array}$ & $\begin{array}{r}987 \\
1052 \\
930 \\
967 \\
946 \\
1023 \\
1030 \\
1010 \\
971 \\
986\end{array}$ & $\begin{array}{l}15.4 \\
14.0 \\
12.8 \\
16.7 \\
14.2 \\
14.0 \\
15.9 \\
18.1 \\
19.5 \\
23.9\end{array}$ & $\begin{array}{r}3 \cdot 9 \\
5 \cdot 1 \\
4 \cdot 0 \\
5 \cdot 6 \\
4 \cdot 3 \\
4 \cdot 6 \\
6 \cdot 0 \\
7 \cdot 4 \\
9 \cdot 0 \\
11 \cdot 4\end{array}$ \\
\hline
\end{tabular}

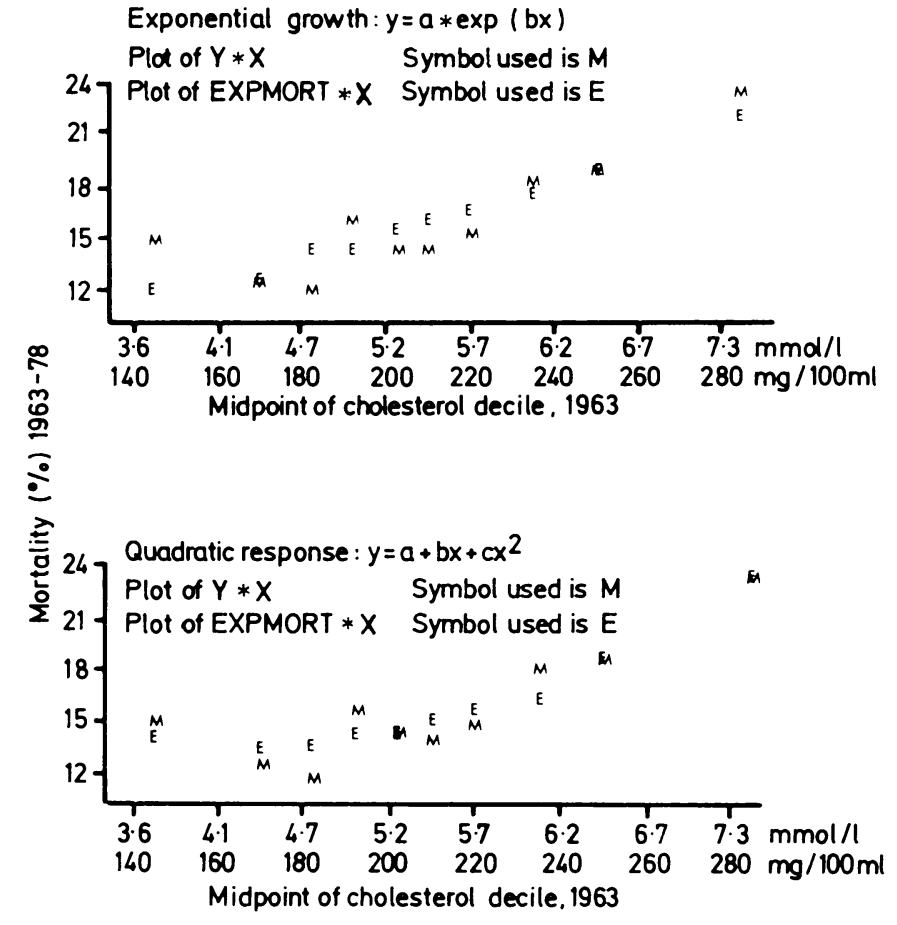

Curvilinear fitting of 15 year mortality rates in deciles of baseline serum cholesterol concentrations. EXPMORT denotes expected mortality rate according to mathematical function.

coronary heart disease associated with an increment of $1 \mathrm{SD}$ in total cholesterol and a decrement of $1 \mathrm{SD}$ in high density lipoprotein cholesterol. All estimated relative risks were appreciably larger than 1 $(95 \%$ confidence intervals listed). Judging by these multivariate results, it appears that a mutual adjustment for risk factors delineates a particular role of high density lipoprotein cholesterol as a determinant of risk. Nevertheless, the multivariate proportional hazards model is insensitive to the possibility of a threshold. ? Thus table VII serves only to suggest that total serum cholesterol had a weaker prognostic power for coronary heart disease mortality over 15 years in this sample than did high density lipoprotein cholesterol. On repeating the Cox regression analysis with a quadratic term added for cholesterol, negligible differences in relative risk estimates were observed. This suggests that total cholesterol, after adjustment for covariates, is very weakly associated with total mortality.

TABLE V-Fifteen year mortality (1963-78) by quintiles of high density lipoprotein cholesterol (absolute concentrations and as percentage of total cholesterol)

\begin{tabular}{|c|c|c|c|c|c|c|c|c|c|}
\hline \multirow{2}{*}{ Quintile } & \multicolumn{2}{|c|}{ High density lipoprotein cholesterol } & \multirow{2}{*}{$\begin{array}{c}\text { No } \\
\text { of } \\
\text { subjects }\end{array}$} & \multicolumn{2}{|c|}{ Age adjusted percentage mortality } & \multirow{2}{*}{$\begin{array}{c}\text { High density lipoprotein } \\
\text { cholesterol/total cholesterol } \\
(\%)\end{array}$} & \multirow{2}{*}{$\begin{array}{c}\text { No } \\
\text { of } \\
\text { subjects }\end{array}$} & \multicolumn{2}{|c|}{ Age adjusted percentage mortality } \\
\hline & $\mathrm{mmol} / 1$ & $\mathrm{mg} / 100 \mathrm{ml}$ & & All causes & Coronary heart disease & & & All causes & Coronary heart disease \\
\hline $\begin{array}{l}\text { I } \\
\text { II } \\
\text { III } \\
\text { IV } \\
\text { V }\end{array}$ & $\begin{array}{r}<0.75 \\
0.75-0.85 \\
0.86-0.96 \\
0.97-1.11 \\
>1.11\end{array}$ & $\begin{array}{r}r 29 \\
29-33 \\
34-37 \\
38-43 \\
>43\end{array}$ & $\begin{array}{l}1224 \\
1463 \\
1213 \\
1331 \\
1316\end{array}$ & $\begin{array}{l}19.8 \\
17.5 \\
15.8 \\
14.5 \\
13.3\end{array}$ & $\begin{array}{l}8 \cdot 8 \\
7 \cdot 7 \\
6 \cdot 6 \\
4 \cdot 6 \\
3 \cdot 8\end{array}$ & $\begin{array}{r}<14 \\
14-15 \\
16-18 \\
19-23 \\
>23\end{array}$ & $\begin{array}{l}1561 \\
1001 \\
1515 \\
1323 \\
1147\end{array}$ & $\begin{array}{l}21 \cdot 2 \\
16 \cdot 0 \\
14 \cdot 3 \\
14 \cdot 5 \\
13 \cdot 1\end{array}$ & $\begin{array}{l}9 \cdot 9 \\
7 \cdot 0 \\
6 \cdot 2 \\
4 \cdot 5 \\
2 \cdot 7\end{array}$ \\
\hline Total & & & 6547 & & & & 6547 & & \\
\hline
\end{tabular}

TABLE VI-High density lipoprotein cholesterol as percentage of total cholesterol and subsequent mortality (1963-78) by age groups

\begin{tabular}{|c|c|c|c|c|c|c|c|c|}
\hline \multirow{2}{*}{ Age (years) } & \multirow{2}{*}{ No of subjects } & \multirow{2}{*}{$\begin{array}{l}\text { Mean high density lipoprotein } \\
\text { cholesterol in } 1963 \\
\left(0_{0}^{\circ}\right)\end{array}$} & \multirow{2}{*}{ No $(\%)$ of deaths $1963-78$} & \multicolumn{5}{|c|}{ Deaths/1000 in high density lipoprotein cholesterol/total cholesterol quintiles* } \\
\hline & & & & I & II & III & IV & $\mathrm{V}$ \\
\hline $\begin{array}{r}40-49 \\
50-59 \\
\geqslant 60\end{array}$ & $\begin{array}{r}3501 \\
2433 \\
613\end{array}$ & $\begin{array}{l}18 \cdot 3 \\
17 \cdot 9 \\
18 \cdot 4\end{array}$ & $\begin{array}{l}294(8 \cdot 4) \\
520(21 \cdot 4) \\
239(39 \cdot 0)\end{array}$ & $\begin{array}{l}115(51) \\
284(138) \\
486(216)\end{array}$ & $\begin{aligned} & 88(45) \\
& 194(71) \\
& 432(205)\end{aligned}$ & $\begin{array}{rr}64 & (25) \\
202 & (95) \\
365 & (142)\end{array}$ & $\begin{aligned} 88 & (26) \\
186 & (58) \\
314 & (102)\end{aligned}$ & $\begin{array}{r}61(8) \\
179(38) \\
342(90)\end{array}$ \\
\hline Total & 6547 & $18 \cdot 2$ & $1053(16 \cdot 1)$ & $212(99)$ & $160(69)$ & $143(62)$ & $145 \quad(45)$ & $131(27)$ \\
\hline
\end{tabular}

*Age specific death rates from coronary heart disease given in parentheses. 
TABLE VII-Contribution of total and high density lipoprotein cholesterol in prediction of 15 year mortality

\begin{tabular}{|c|c|c|}
\hline \multirow{2}{*}{ Variable } & \multicolumn{2}{|c|}{ Adjusted relative risk } \\
\hline & Estimate & $95 \%$ Confidence interval ${ }^{*}$ \\
\hline \multicolumn{3}{|c|}{ Coronary heart disease mortality ${ }^{\dagger}$} \\
\hline $\begin{array}{l}\text { High density lipoprotein cholesterol } \\
\text { Total cholesterol }\end{array}$ & $\begin{array}{l}1 \cdot 45 \\
1 \cdot 29\end{array}$ & $\begin{array}{l}1 \cdot 35,1 \cdot 54 \\
1 \cdot 16,1 \cdot 42\end{array}$ \\
\hline \multicolumn{3}{|c|}{ Total mortality } \\
\hline $\begin{array}{l}\text { High density lipoprotein cholesterol } \\
\text { Total cholesterol }\end{array}$ & $\begin{array}{l}1.13 \\
1.07\end{array}$ & $\begin{array}{l}1.07,1 \cdot 21 \\
1.01,1.14\end{array}$ \\
\hline
\end{tabular}

*95\% Confidence interval shown as lower and upper limits for estimated risk, calculated by proportional hazards model.

Coronary heart disease mortality (345 deaths) analysed only in men with no documented myocardial infarction before study.

Relative risk estimated is that associated with $1 \mathrm{SD}$ change of predicting variable (total cholesterol, increase; high density lipoprotein cholesterol, fall) and adjusted for the following variables: age, diabetes and angina at entry, systolic blood pressure cigarette smoking, ethnic origin, education, relative weight, reported intake of
saturated fat, and serum urate concentrations.

\section{Discussion}

The relation between the serum cholesterol concentration and the incidence of atherosclerosis is unresolved and of major importance. Realistically the question must be approached by studying the association of cholesterol with coronary heart disease morbidity or mortality rates.

In practical terms the major issue is whether a sweeping attempt to lower the mean cholesterol concentration of populations is justified. In terms of the message often delivered to the public, the following question might be put: Should everyone eat as though he (or she) is prone to hyperlipidaemia ? On the basis of our results it would appear that at concentrations below $6.2 \mathrm{mmol} / 1(240 \mathrm{mg} / 100 \mathrm{ml})$, and certainly below $5.7 \mathrm{mmol} / 1(220 \mathrm{mg} / 100 \mathrm{ml})$, there is little or no association between cholesterol concentration and risk of mortality from coronary heart disease. Whether the link is fully with incidence or partly mediated through case fatality we cannot judge with certainty. Of equal relevance in our opinion is judging the efficacy of reducing cholesterol against the yardstick of the reduction in total mortality. Our results are not very suggestive when this latter criterion is applied. Even in the recent, widely publicised Lipid Research Clinics primary prevention study of the National Heart, Lung, and Blood Institute no significant reduction of overall mortality was achieved (the reduction was $7 \%$ ), although the authors did not attribute major importance to that point, the difference being due to excess traumatic deaths in the drug treated group. ${ }^{1}$

Several population studies have detected associations between cholesterol and coronary heart disease that closely resemble our results. ${ }^{18-22}$ Keys pointed out that the sweeping use of multivariate analysis has led to the observing of $\mathrm{L}$ shaped or $\mathrm{J}$ shaped associations by forcing the association into the best fit with linearity. ${ }^{7}$ This best fit may often be poor. To avoid the temptation to "smooth at all cost" we need to look at tertiles, quintiles, or deciles, as the magnitude of the numbers permits.?

Our results offer little support for the "population strategy." Although many cases of coronary heart disease will occur among those at low or moderate risk, our knowledge about the determinants of coronary heart disease incidence and mortality is far from adequate, and the widely varying results of recent multiple intervention studies are evidence of this gap in our knowledge. ${ }^{23}$ Hence we cannot recommend a policy of reducing the mean cholesterol concentration in populations to $4.7 \mathrm{mmol} / 1$ $(180 \mathrm{mg} / 100 \mathrm{ml})$, which in any case would be a major, if not impossible task. We therefore concur that a policy of selective intervention should be followed and that the cholesterol concentration should be reduced, if possible, in those in whom it is definitely raised, with means of attempting the reduction (dietetic, pharmacological) tailored individually. This might preclude the exposure of a large section of the population to potential drug hazard.
A special feature of our study was the availability of data for a long term association of mortality with high density lipoprotein cholesterol. The latter variable was related to mortality from coronary heart disease in a near perfect linear manner when analysis was performed in quintiles of the relative (high density lipoprotein/total) lipid values. Lowest quintile/highest quintile relative risk was $3 \cdot 7$, as compared with the highest quintile/lowest quintile relative risk of only 2.3 for total cholesterol.

If high density lipoprotein cholesterol is the major lipid determinant of long term coronary heart disease and total mortality and the ratio of high density lipoprotein cholesterol to total cholesterol is the better identifier of risk, as we have suggested ${ }^{24}$ and as the present univariate and multivariate analyses suggest, the prospects for modifying coronary heart disease risk merely through recommendations to whole populations to introduce massive dietary changes are poor. Recently, parallel changes in high density lipoprotein and total cholesterol, under dietary control, were observed in Finland. ${ }^{25}$ The effect of cholestyramine resin may have been primarily due to the success of introducing pharmacological intervention that reduced low density lipoprotein while avoiding a parallel decline in high density lipoprotein and thus causing major changes in individual high density lipoprotein to low density lipoprotein ratios.

A final point is related to the widespread opinion that, at least across populations, the lower the mean cholesterol concentration the lower the risk of coronary heart disease. The example of the Israeli women who, despite a mean plasma cholesterol concentration of under $5 \cdot 2 \mathrm{mmol} / 1(200 \mathrm{mg} / 100 \mathrm{ml}),{ }^{26}$ rank so high on the international mortality list ${ }^{27}$ is a reminder that high cholesterol values and coronary heart disease are not synonymous. Data for women were clearly ignored or discarded when the "ecological" type of diet-cholesterol-coronary heart disease argument was proposed. Inconsistencies may stem from unrecognised interactions among environment, sex, and other genetic factors. ${ }^{28} 29$

In conclusion, these data from the 15 year follow up of the Israeli Ischaemic Heart Disease Study support the "threshold theory" for the association between cholesterol and mortality, suggest that high density lipoprotein cholesterol might be a key variable, and provide a further indication that the unqualified recommendation for mass dietary changes in whole populations may be premature.

The baseline and seven year mortality data in this study were collected in the framework of the Israeli Ischaemic Heart Disease Study (Jack H Medalie, director; Professors J H Medalie, H N Neufeld, and E Riss, principal investigators). The classification of deaths for the first seven years was done by Professor Medalie and Dr P H Sive and thereafter by Dr E Holtzman. We are indebted to Ms S Yaari for computer programming. Computerised records of mortality were made available by the Central Bureau of Statistics, Jerusalem. Collection and analysis of data during 1963-78 were supported by counterpart funds PL480, research agreement No 375106 with the USA National Heart, Lung, and Blood Institute, Bethesda, Maryland. Performance of the 15 year follow up was supported by the Basic Research Foundation, Israeli Academy of Sciences and Humanities, Jerusalem.

\section{References}

1 Lipid Research Clinics Program. The Lipid Research Clinics coronary primary prevention trial results 1 . Reduction in incidence of coronary heart disease. fAMA 1984;251:351-64.

2 Oliver MF. The cholesterol-coronary question: why not a policy of selective intervention? Int $\mathcal{F}$ Cardiol 1983;4:201-6.

3 American Heart Association Nutrition Committee. Rationale of the diet-heart statement of the American Heart Association. Circulation 1982;65:839-54A. Blackburn H, Jacobs D. Coronary disease risk factors: a population view. In Schettler G, Gotto AM, Middelhof G, Habenicht AJR, Jurutka KR, eds Atherosclerosis VI. Proceedings of sixth international symposium on athero sclerol W. B Gringer-Verlag, 1983:733-44.

5 Kannel WB, Gordon T. The optimum serum cholesterol. Lancet

7 Keys A. The optimum serum cholesterol. Lancet 1982;ii:656.

8 Lewis B. The optimum serum cholesterol. Lancet 1982;ii:815.

9 Reiser R. Oversimplification of diet: coronary heart disease-relationship and exaggerated diet recommendations. Am f Clin Nutr 1978;31:865-75. 
10 WHO Expert Committee. Prevention of coronary heart disease. WHO Tech

Rep Ser 1982 ; No 678 .
11 Hjermann I, Byre KV, Holme I, Leren P. Effect of diet and smoking intervention on the incidence of coronary heart disease. Report from the Oslo study group

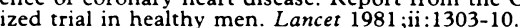

12 Groen JJ, Medalie JH, Neufeld HN, et al. An epidemiologic investigation of hypertension and ischemic heart disease within a defined segment of the adult hypertension and ischemic heart disease within a defined
male population of Israel. Isr f Med Sci $1968 ; 4: 177-94$.

13 Kahn HA, Medalie JH, Neufeld HN, Riss E, Balogh M, Groen JJ. Serum cholesterol: its distribution and association with dietary and other variables in cholesterol: its distribution and association with dietary and other variables in
a survey of 10,000 men. Is $f$ Med Sci $1969 ; 5: 1118-27$.

Anderson JT, Keys A. Ch

5 Burstein M, Samaille J. Sur une dosage rapide du cholesterol lie aux $\alpha$ et aux 3-lipoprotein du serum. Clin Chim Acta 1960;5:609-11.

6 Snedecor GW, Cochran WG. Statistical methods. 6th ed. Ames, Iowa: Iowa State University Press, 1967:246-8, 449-53.

17 Cox DR. Regression models and life tables. Fournal of the Royal Statistical Society $B$ 1972;34:187-220.

18 Dyer AR, Stamler J, Paul O, et al. Serum cholesterol and risk factor of death from cancer and other causes in three Chicago epidemiological studies. $\mathcal{F}$
Chronic Dis $1981 ; 34: 249-60$.

19 Rose G, Reid DD, Hamilton PJS, McCartney P, Keen H, Jarret RJ. Myocardial ischaemia risk factors and death from coronary heart-disease. Lancet 1977; ii

20 Holme I, Helgelund A, Hiermann I, Leren P, Lund-Larsen PG. Four and two-third years incidence of coronary heart disease in middle-aged men: the Oslo study. Am $\mathcal{F}$ Epidemiol 1980;112:149-60.

21 Böttiger LE, Carlson LE. Risk factors for ischemic vascular death in men in the Stockholm prospective study. Atherosclerosis $1980 ; 36: 389-408$.

22 Pooling Project Research Group. Relationship of blood pressure, serum cholesterol, smoking habit, relative weight and ECG abnormalities to incidence $1978 ; 31: 201-306$.

23 Oliver MF. Targeting coronary risk factor control. Lancet 1983 ;i :449-50.

24 Yaari S, Goldbourt U, Even-Zohar S, Neufeld HN. Associations of serum high density lipoprotein and total cholesterol with total, cardiovascular and cancer mortality in a 7-year prospective study of 10,000 men. Lancet 1981 ;i:1011-5. 25 Ennholm C, Huttonen JK, Pietinen $P$, et al. Effect of diet on serum lipoproteins in a population with a high risk of coronary heart disease. $N$ Engl $\mathcal{F}$ Med

26 Halfon S-T, Rifkind BM, Harlap S, et al. Plasma lipids and lipoproteins in dult Jews of different origins : the Jerusalem Lipid Research Clinic prevalence study. Isr f Med $S c i$ 1982;18:1113-20.

27 Goldbourt U, Kark JD. The epidemiology of coronary heart disease in the ethnically

28 Harper AE. Coronary heart disease-an epidemic related to diet? Am 7 Clin Nutr 1983;37:669-81.

29 Neufeld HN, Goldbourt U. Coronary heart disease: genetic aspects. Circulation 1983;67:943-54.

(Accepted 14 Fanuary 1985)

\title{
Racial and other characteristics of human $T$ cell leukaemia/ lymphoma (HTLV-I) and AIDS (HTLV-III) in Trinidad
}

\author{
C BARTHOLOMEW, W CHARLES, C SAXINGER, W BLATTNER, M ROBERT-GUROFF, \\ C RAJU, P RATAN, W INCE, D QUAMINA, K BASDEO-MAHARAJ, R C GALLO
}

\begin{abstract}
Adult $T$ cell leukaemia/lymphoma was first recognised as a clinical entity in southwest Japan. Subsequently the Caribbean has been found to be another area where the disease is endemic, and sporadic cases have been identified in different parts of the world. The human T cell leukaemia/lymphoma virus (HTLV-I) is causally related to adult $T$ cell leukaemia/lymphoma. A subgroup of HTLV, designated HTLV-III, has recently been isolated from many patients with the acquired immunodeficiency syndrome (AIDS) and preAIDS, and there is now evidence that this variant is the primary cause of AIDS. This is the first report from Trinidad to describe 12 cases of adult $T$ cell leukaemia/lymphoma and 14 of AIDS. All were in patients of African descent. No cases were seen in subjects of East Indian descent, who, like those of African descent, comprise as much as $40 \%$ of the population.
\end{abstract}

\footnotetext{
The General Hospital, University of the West Indies, Port of Spain, Trinidad WI

C BARTHOLOMEW, MD, FRCP, professor of medicine

W CHARLES, MRCPATH, consultant haematologist

C RAJU, MRCPATH, consultant pathologist

P RATAN, FRCP, consultant physician

W INCE, FRCP, consultant physician

D QUAMINA, FRCP, consultant dermatologis

$\mathrm{K}$ BASDEO-MAHARAJ, MB, registrar in dermatology
}

Laboratory of Tumor Cell Biology, National Cancer Institute, Bethesda, Maryland

C SAXINGER, PHD, microbiologist

M ROBERT-GUROFF, PHD, biologist

R C GALLO, MD, chief

Environmental Epidemiology Branch, National Cancer Institute, Bethesda, Maryland

W BLATTNER, MD, chief, family studies section

Correspondence and requests for reprints to: Professor C Bartholomew.
West Indians of African descent may have increased susceptibility to infection with both HTLV-I and HTLVIII.

\section{Introduction}

Retroviruses have been linked to leukaemia in many animal species, and the search for a human retrovirus was first accomplished with the discovery of a type $C$ retrovirus of truly human origin by Gallo and coworkers, which was quite distinct from any known animal retrovirus. This agent, the human $T$ cell leukaemia/lymphoma virus type I (HTLV-I), was initially isolated from two black adults said to have mycosis fungoides and the Sézary syndrome ${ }^{12}$ but who in retrospect had adult $\mathrm{T}$ cell leukaemia/lymphoma.

The link of HTLV-I to this clinical entity was made in serological studies of Japanese patients with adult $\mathrm{T}$ cell leukaemia/lymphoma, by the recognition that HTLV-I associated patients in the United States had this syndrome, and by the observation of the clinical syndrome in six black patients in London who originated from the West Indian islands St Vincent, Grenada, and Trinidad and from Guyana, ${ }^{3}$ all of whom were shown to be positive for HTLV-I antibodies. ${ }^{4}$ Before this, no such cases had been reported in West Indians living in the West Indies.

Subsequently the detection of antibody positive carriers in the region supported the concept that the West Indies are an HTLV-I endemic region. ${ }^{5}$ Further support for this concept has come from studies in Jamaica, ${ }^{6}$ where $11(69 \%)$ of 16 consecutive patients with non-Hodgkin's lymphoma newly diagnosed between 1 February 1982 and 31 January 1983 had antibodies to HTLV-I in their sera.

A retroviral aetiology for the acquired immune deficiency syndrome (AIDS) was suggested initially by the finding of antibodies to HTLV-I in a high proportion of patients with AIDS, using an HTLV-I membrane antigen assay. ${ }^{7}$ AIDS is, however, rare or absent in most areas where HTLV-I is endemic. This discrepancy has been clarified by the recent 